\title{
Standard Terms in the Banking Service Contracts and Its Practical Problems (According to the Legislation of Georgia)
}

\author{
Tamar Chitoshvili \\ Doctor of Law, Professor \\ Iv. Javakhishvili Tbilisi State University, Faculty of Law \\ 1, I.Chavchavadze Ave., Academic Building I, 0179 Tbilisi, Georgia \\ Tbilisi Humanitarian Teaching University, Faculty of Law \\ 31, Monk Gabriel Salos Ave., 0144 Tbilisi, Georgia
}

\begin{abstract}
Resume
The basis for the regulation of relations between the subjects in the private legal relationship is mainly the contract. Therefore, the proper regulation of these relations depends on the correct determination of content of the contract, in order for the vague and ambiguous expressions not to take place. Proper drafting and implementation of the content of the contract must equally protect the interests of the parties. In this regard, the contracts with standard terms and the results of fulfilling these terms are the most problematic. When drafting the content of both individual and standard types of contracts, it is necessary to adhere to the principle of good faith to the highest degree within the framework of lawful maintenance of contractual freedom. Based on this, achievement of mutually acceptable legal results and protection of the rights of consumers will be possible. It is necessary to establish the legal mechanism for controlling the content of contracts with standard terms.
\end{abstract}

Key words: Contract, standard terms, good faith, freedom of contract, bank agreement.

\section{Introduction}

The Legislation of Georgia does not contain a legislative definition of the concept of a contract, but the Article 50 of the Civil Code of Georgia provides an explanation of the transaction, namely: A transaction is unilateral, bilateral or multilateral declaration of intent aimed at creating, changing or terminating a legal relation. This definition also includes the elements of the contract, especially if we use the doctrinal definition that all contracts are the transactions and not all the transactions are the contracts.

The contract defines the contract law and its freedom.

Based on the fulfillment of the terms and conditions stipulated by the contract, the legal consequences, that the parties to the contract wish, arise.

Although the Civil Code of Georgia covers almost all common types of contracts, however, this list is not exhaustive. The right of an action not prohibited by law (Article 10 of CCG) implies the conclusion of a contract not provided by law (Book III, Editor: L. Chanturia, 2019, p.56).

Each type of contract is of individual nature. Accordingly, each individual contract may have a different structure. However, there are provisions that are found in the majority of contracts with more or less difference. Accordingly, they belong to the general provisions and their existence in contract law bears both freedom and restrictive function.

The basis for the occurrence of a contractual obligation depends mainly on the will of the parties; however, the voluntarism nature of this basis does not imply that it is entirely free from the legislative voluntariness. This is clearly evidenced by the fact that the content of a particular contract is formed exactly through the interrelation of imperative and dispositional norms. This is typical for all types of contracts. (T. Chitoshvili, 2015, p. 38)

The basis for free determination of the content of a contract is mostly the dispositional norms. The dispositional norms are also applied when there are some issues not addressed by parties in the already concluded contract, or they relied on the rule of law and therefore left the issue uncovered; such uncovered relations are governed by the rule of law. (L. Chanturia, 1997, p. 342)

\section{Interrelation between the freedom and good faith in the contract with standard terms}

Freedom of contract type implies the right of the parties to determine for themselves what type of contract they conclude, i.e. to "invent" for themselves the type of contract that best reflects their relationships, obligations and rights. (G. Svanadze, p.102)

The freedom of contract mainly relates also to the potential to freely determine its content, which is possible on the basis of dispositional norms. 
The Civil law strengthens the presumption of good faith, i.e. the good will. This means the assumption that the participants of the relationship exercise their rights in good faith. (L. Chanturia, 2011, p. 86)

The principles of European contractual law directly stipulate that the parties may freely enter into a contract, determine its form and content in accordance with the principles of good faith and fairness if the contract does not conflict with the imperative norms set forth in the "Principles of European Contract Law" (PECL) (Article 1:102). Adherence to these principles is equally mandatory for both physical and legal entities.

Formal contractual freedom implies the right granted to a private legal entity to conduct its legal activities individually. Therefore, the point is his/her competence with regard to making a legal decision. (Kathleen Sedlmeier - 2012, seite-26)

Adherence to the principle of good faith is mandatory even in pre-contractual negotiations, as the main contract is its direct result.

In the process of pre-contractual negotiations one of the parties may act in bad faith - to mislead the other party through presenting the false information, etc. Due to such actions, the party may be imposed the certain responsibility, regardless concluding/not concluding the contract between the parties. (G. Svanadze, 2014, p.111)

The process of concluding a contract is characterized by different features and circumstances, as a result of which different types of contracts arise.

"Offer - is a proposal to enter into a contract, which should be clearly stated that will make it easier for the acceptor to make decision on the conclusion of the contract. As a rule, the offer must contain the essential terms and conditions of the future contract(G. Svanadze, 2014, p.117)". The individual types of contracts are characterized by the mentioned rule of making a contract, that is the result of preliminary negotiations and the terms and conditions of which are determined by mutual agreement.

A contract with standard conditions differs from individual type contracts.

The need for connection between the freedom of making a contract and good faith is also conditioned by the fact that the content of the contract may not be formally illegal, but, if the interests of only one party are taken into account, then such transactions, in their essence, violate the public order and impede the civil turnover. (Decision \#2b/4686-13)

The harmony of freedom of making a contract and good faith is often violated in a relationship regulated by a contract with standard terms.

According to Article 342 of the Civil Code of Georgia: "Standard contract terms are provisions prepared in advance for repeated use that one party (the offeror) proposes to the other party, and which lay down rules that deviate from, or supplement statutory provisions".

Preliminary formulation of contractual terms and conditions for multiple contracts significantly differs from individual and general business contracts. The essential purpose of preliminary formulation is mainly the multipleuse but not its objective suitability. Repeated use of the terms and conditions of the contract is the sole purpose of the author and it is not necessary for the consumer. (Dr. JörgFritzsche, Dr.Kai-Oliver Knops, 2018, seite-25)

It is essential that the offeror, or his/her assistant, raise a demand to the client to use the standard terms of preestablished contract (comments to the Civil Code, Book III, p. 185)

The pre-established standard terms mainly serve the essential interests of one party, i.e. the party determining these terms. In addition to the fact that the standard terms of the contract protect the interests of its authors more than the interests of the consumers, its advantage is also revealed in saving the time, because once established contractual terms and conditions are intended for unspecified users. Therefore, standard type contracts mainly serve the business and are found in the field of activities provided by commercial legal entities. Such legal entities hold a dominant position, which further creates problems regarding the protection of consumers' rights.

When determining the standard terms of a contract, the principle of good faith is often violated, this should be of the highest possible degree in private law and, in particular, in contractual relationship. Consequently, the equality of parties is violated, which is the main principle in private legal relations.

The party determining the terms and conditions must clearly interpret and provide clear information on the content of the contract to the other party.

Inadequate information implies misinterpretation by the debtor, which is a breach of obligation and, therefore, leads to both ineffective results and responsibility for breach of obligation. (Lieb/langen, seite-3534) 
The principle of good faith is directly provided for in the general norm of the Civil Code of Georgia, in particular, under the paragraph 3 of Article 8, according to which "the participants in a legal relationship shall exercise their rights and duties in good faith".

In addition to the above-mentioned norm, paragraph 2, Article 319 of the Civil Code of Georgia also provides a special stipulation for those subjects of legal relation that are distinguished by a special position in business, in particular: "If one of the parties to a contract holds a dominant position in the market, then it shall be bound by the obligation to enter into a contract in this field of activity. This party may not unjustifiably offer unequal contractual terms to another contracting party". This norm imperatively establishes the observance of the principle of good faith when concluding a contract by the subjects having the dominant position at the market. This protects the interests of ordinary consumers as well.

The mechanism of legal protection of the principle of good faith is even more pronounced in the special norms of the Civil Code of Georgia (342-348). Under these norms, the contracts with standard terms established in violation of the principle of good faith are void.

A specific condition of the contract may also be considered void, which is directly indicated by a special article (346) of the Civil Code of Georgia, according to which: „Standard terms of a contract shall be void, notwithstanding their inclusion in the contract, if they disadvantage the other party to the contract and are irreconcilable with the principles of trust and good faith. In addition, account shall be taken of the circumstances in which these terms have been included in the contract, also the mutual interest of the parties, etc".

Under this norm the freedom of the party establishing the standard terms is restricted within the framework of legal good faith, if this violates the interests of the other party.

\section{The problem of good faith in terms of bank contracts}

Unfair attitude and its ineffective results for the consumer are mostly revealed in the field of banking when using contracts with standard terms.

Based on free contractual relationships, the banks and credit institutions engage the consumers in processes with seemingly attractive terms and conditions. Due to minimal knowledge, the consumer fails to properly assess the results of the proposed, often void, standard terms and conditions at pre-contractual negotiation stage, and he/she is subject to cabal conditions legally.

Freedom of contract often creates a distinctly advantageous situation for banking institutions, establishing the standard terms.

Protection of rights of credit recipients is in unreliable condition. The consumers mainly sign the standard type contracts, which include many illegal clauses and it is practically unattainable for them to make any changes to the text, because bringing forward the standard terms implies the case where the counterparty has no any legal means to change or have any effect on the content of the standard terms of the contract.

Such clauses of the contract are used by credit-giving entities purposefully, often unreasonably, for their benefit.

The standard terms, while the actual equality between the parties is provided, should not cause the problems, however, weak positions of consumers have the opposite effect in consumer relationships. The reasons for this are economically strong business positions and less consumer awareness or less initiative, proceeding from not so high value of daily transactions. In some cases the same logic may apply to non-consumer counterparties, where the offeror bears more market power. (V. Zaalishvili, p. 186)

The German doctrine expresses the opinion that the confusion of a contractual parity during conclusion of a contract is primarily caused by unprofessionalism of the consumers, the instrument of compensation of which is that the parties provide each other with relevant information on conclusion of the contract, established by law for each business sector. Where there is a lack of information, the parity of the contract is violated. The law confers the customer the right to withdraw from undesirable contract even later. (Dr.Dr.h.e. Peter Bulow; Dr. Markus Artz, 5 Aufgabe, seite 12)

The principle of equality and freedom of making a contract, which mainly relates to the content of the contract, should be further protected when drafting and concluding a contract with standard terms, because a consumer, who does not participate in the drafting of this contract, should not be in a difficult situation. Protection of consumer in such types of contracts greatly depends on the legal good faith of the party determining the standard terms and conditions.

Despite the provisions of the Civil Code of Georgia $(8,319,342-348,115)$ or other legislation, it is often impossible to avoid the risks associated with the protection of consumer rights. Practice shows that freedom of the standard form of contract must be separated from the freedom of content. In many cases, the content of standard terms is devoid of the principle of good faith. This is due to the bed faith of the party setting the standard terms. 
The study of judicial practice has established that there are frequent cases when the standard terms of the contract concluded by the bank, as unilateral terms and conditions, contradict the legislative requirements, in addition, the principle of good faith is violated. Such contracts, or specific terms and conditions of this contract, are often annulled by the court. For example, according to one of the court decisions the provision stipulated by the bank under the standard contract was annulled, by which the origin of the obligation to pay the penalty and interest depended on the condition - prosecution of claim. The contract with such provision is void because it contradicts the law. (Book \#4, p.167)

Non-compliance with the requirements of the law with content with standard terms occurs when the party, which determines the terms and conditions unilaterally, does not take into consideration the interests of the consumer and seeks to determine the content of the contract only in its best interests.

The freedom of contract has often not-so-desirable results for consumers, mainly in the activities of legal entities.

The contracts in the banking system mainly represent the contracts with standard terms, the content of which is drawn up unilaterally and unfairly. Such contracts include vague and comprehensive terms and conditions, based on which the consumer (the bank's client) is often subject to unclear legal space and becomes a victim of vague terms and conditions. For example, by studying the practice it becomes clear that the client (consumer) signs a standard contract drawn up by the bank, which includes the same terms for fixed term and open ended contracts, as well as the same rules for termination of these contracts both prematurely and at term. The terms and conditions of the contract concluded for different terms are often given in the contracts concluded for specific terms. Also, the standard terms of illegal nature are often revealed, for example: the bank is authorized at any time to unilaterally change this or that standard terms, interest, term, etc. of the contract, which is very vague not only for consumers of any profession, but also for lawyers themselves. In addition, the attitude towards the fulfillment of such terms acquires a binding character. Unconscious fulfillment of such terms often leads to a violation of the interests of consumer and brings him/her to a cabal conditions.

Thus, in the practice of banking activity there is often a contract with only one content with standard terms, the signing of which are offered to all consumers, for whom it becomes unclear, which terms of such contract correspond to its specific rights and obligations. Therefore, the consumer often becomes a victim of a contract.

It should be taken into consideration that since there are different types of banking services, the standard terms of appropriate contract must be determined separately for each of them, which will be offered only to those consumers who enjoy a particular type of banking service.

The contracts with standard terms drawn up based on such principles will further protect the interests of consumers and will not be focused on protecting the interests of the party, which defines the terms and conditions unilaterally; this will also lead to fewer disputes.

Based on the analysis of practice, according to the explanation made by the Supreme Court, "the Civil Code of Georgia provides the principle of free conclusion of a contract, as well as free defining of its content, however, in some cases intervention is required by the legislature on the one hand, which is practicable based on the imperative norms and, on the other hand, through the rightful interpretation of the law, or the terms of the contract by the court, in accordance with mutual interests of the parties; this ensures the protection of civil turnover as a value. The court has the opportunity to determine and establish fair terms and conditions during compulsory counter parting. Articles 319 and 325 of the Civil Code of Georgia bear exactly such normative content. The right provided for the above-mentioned norms that the "weak" party to the contract shall refrain from the action of unfair provision of the contract and the obligation of the court to protect this right is aimed at the replacing of a formal balance, which is reinforced by the contract through redistribution of rights and obligations, with the effective balance, which restores the equality between the parties". (Book \#10, 2018, Supreme Court of Georgia, pp.7-8)

According to the court the definition of "weak side" does not imply the status of a person but implies his/her condition taking into account various factors. (Book \#10, 2018, p.8)

According to Article 115 of the Civil Code of Georgia, the right may not be misused with a sole intention to inflict damages on another person. In case of abusing of rights, when the principle of good faith is violated, the first duty of the court during review of dispute is to ensure the lawful exercising of civil rights. For this purpose, the legality of the content of the contract with standard terms is checked. (Book \#17, 2017, p.170)

The study and generalization of practice, especially in the field of banking, gives the impression that a legislative mechanism for controlling the content of a contract with standard terms needs to be changed.

Thus, the activities of legal entities operating in the field of banking mainly rely on the contract law, the content of which is determined by standard terms. 
The legal mechanism for monitoring the compliance of the content of the contracts with standard terms with the current legislation drawn up by the banking institutions should be established, which provides protection of rights of especially those consumers, who have to be involved in contracts operating in the banking field.For this purpose, it is necessary that the current legislation of Georgia focused on the protection of consumer rights, to come into compliance with the international legislation on the protection of consumer rights.

\section{Literature:}

Professor, Doctor: Giorgi Svanadze, - the Contract as a basis for arising of obligation; published in the collection Contract Law, Editor: Giorgi Jugheli, USAID, Publishing House "Meridiani", 2014, p.102; p.111; p.117; p. 187

Professor, Doctor: Tamar Chitoshvili - Content and types of obligations arising from obligatory-legal relationship, Tbilisi, 2015, p.38

Comments to the Civil Law, Book III, Articles 316-476, Editor: Professor Lado Chanturia, USAID, 2019, p.56; p. 185

Professor, Doctor: Lado Chanturia, General Part of Civil Law, Publishing House „Samartali“, 2011, p.86

Professor, Doctor: Lado Chanturia, Introduction to the General Part of Civil Law of Georgia, Publishing House „Samartali“, 1997, p.342

Professor, Doctor: Tamar Lakerbaia; Professor, Doctor: Vakhtang Zaalishvili; Professor, Doctor: Tamar Zoidze; Law on Protection of Consumer Rights (A way of harmonization with European law), IBSU, Tbilisi, 2018. p. 186

Lieb/langen, Schuldrecht (Obligatory Law), Band 2/2, 3. Aufgabe, Nomos, DeutscherAnwaltVerein, seite-3534

BürgerlichesGesetzbuch, Schuldrecht 2 (Civil Code, Obligatory Law), \$\$305-310, bearbeitet von: Professor Dr. JörgFritzsche, Professor Dr.Kai-Oliver Knops, 2018, seite-25

Dr.Dr.h.e. Peter Bulow; Dr. Markus Artz, (Schwerpunktbereich) Verbraucherprivatrecht, 5 Aufgabe, seite 12

Kathleen Sedlmeier - RechtsgeschäftlicheSelbstbestimmungimVerbrauchervertrag (Legal regulation of consumer agreement), StudienzumPrivatrecht 21, 2012 regulation), seite-26

Collection of Decisions of the Supreme Court of Georgia, Obligatory Law (General Part), Book \#10, 2018, p.7-8

Collection of Decisions of the Supreme Court of Georgia, Obligatory Law (General Part), Book \#10, 2018, p.8

Collection of Decisions of the Supreme Court of Georgia, Contract Law, Book \#17, 2017, p.170

Decision \# 2b/4686-13 of 15 April 2014 of Tbilisi Court of Appeals 